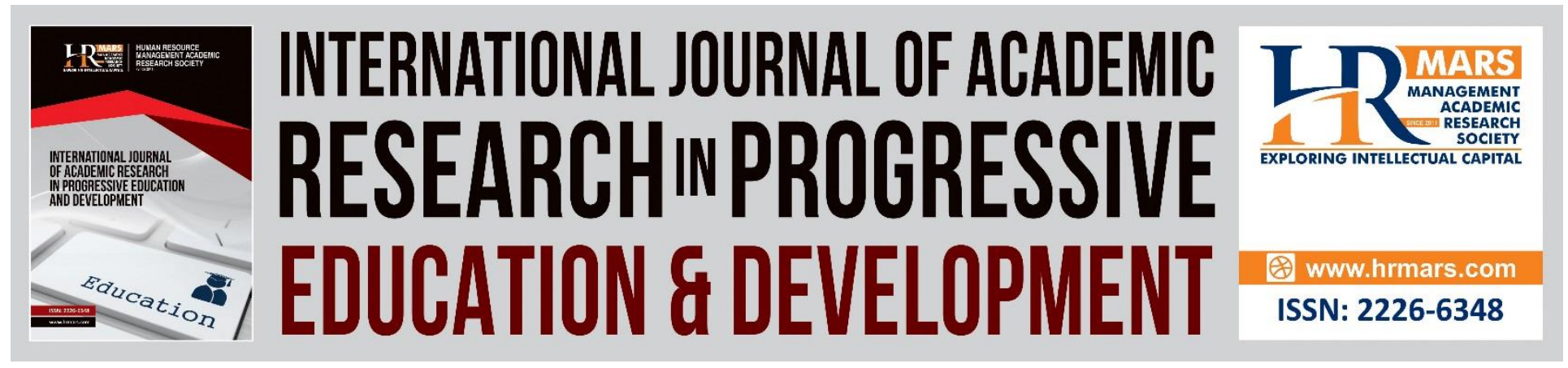

\title{
Students' Knowledge of the Readiness to Use E-Learning
}

\section{Nor Haliza Che Hashim, Kamisah Osman}

To Link this Article: http://dx.doi.org/10.6007/IJARPED/v10-i2/10142

DOI:10.6007/IJARPED/v10-i2/10142

Received: 06 April 2021, Revised: 11 May 2021, Accepted: 27 May 2021

Published Online: 08 June 2021

In-Text Citation: (Hashim \& Osman, 2021)

To Cite this Article: Hashim, N. H. C., \& Osman, K. (2021). Students' Knowledge of the Readiness to Use ELearning. International Journal of Academic Research in Business and Social Sciences, 10(2), 596-604.

Copyright: (C) 2021 The Author(s)

Published by Human Resource Management Academic Research Society (www.hrmars.com)

This article is published under the Creative Commons Attribution (CC BY 4.0) license. Anyone may reproduce, distribute, translate and create derivative works of this article (for both commercial and non-commercial purposes), subject to full attribution to the original publication and authors. The full terms of this license may be seen

at: http://creativecommons.org/licences/by/4.0/legalcode

Vol. 10(2) 2021, Pg. 596 - 604

http://hrmars.com/index.php/pages/detail/IJARPED

JOURNAL HOMEPAGE

Full Terms \& Conditions of access and use can be found at http://hrmars.com/index.php/pages/detail/publication-ethics 


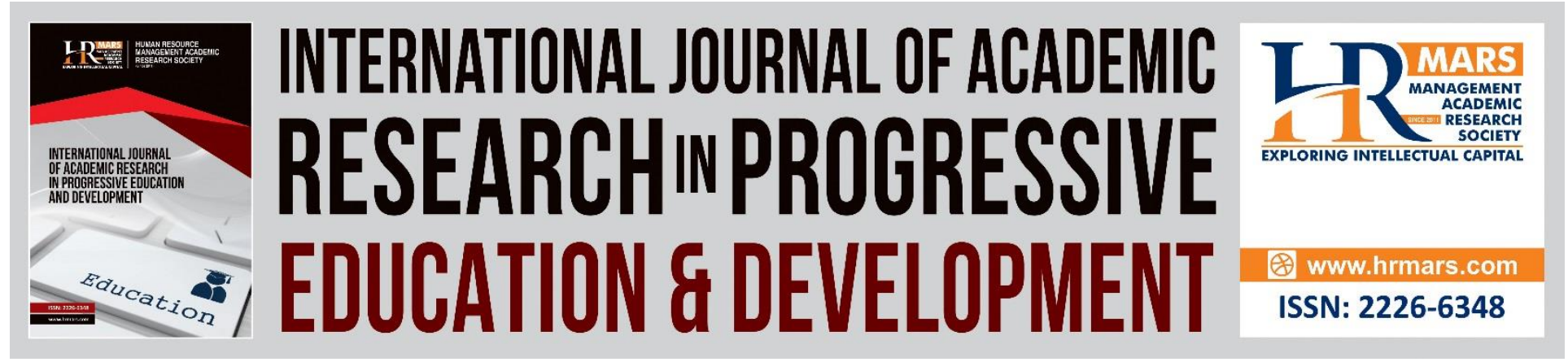

\title{
Students' Knowledge of the Readiness to Use E- Learning
}

\author{
Nor Haliza Che Hashim, Kamisah Osman \\ Faculty of Education, Universiti Kebangsaan Malaysia, Bangi, Selangor, Malaysia \\ Email: halyzahashim@gmail.com, kamisah@ukm.edu.my
}

\begin{abstract}
E-learning has become a new norm in the world of education nowadays. Rapid development in educational technology leads to the improvement and simplification of traditional teaching and learning methods. Furthermore, today's learners want relevant, mobile, and self-paced content. This need is fulfilled with the online learning platform, allowing students to learn at their comfort and pace. E-learning helps teachers in preparing, distributing, and evaluating the assignments given to students. Teachers and lecturers have now become the facilitator to their students in the learning process. This study was conducted to identify the level of knowledge on the readiness to adopt e-learning among form six students in the science stream at a form six college in Selangor. This study follows the quantitative research approach, and a questionnaire was used as the instrument to collect the data. 31 respondents were involved in this research. The findings show that the level of knowledge of the readiness to use e-learning among science students in Tunku Abdul Rahman Putra Form Six College (KiSTARP) is high, with the mean score at 3.82. Elearning makes it easier for teachers to give students assignments, thus enabling teachers to monitor students' presence and readiness to learn. This limitless technology allows the teaching and learning process to occur at any time and improves the two-way communication between teachers and students. It also helps create meaningful learning experiences, which will benefit both teachers and students.
\end{abstract}

Keywords: E-Learning, Knowledge, Readiness

\section{Introduction}

Rapid development in educational technology has changed the process of teaching and learning. At the early stages, e-learning is more focused on strategies to share information among people. The availability of Web 2.0 applications such as blogs, podcasts, wikis, Facebook and YouTube, has brought changes to the concept and criteria of E-learning Web 1.0, which was focused on information distribution strategies. In the meantime, e-learning 2.0 is more focused on aspects of communication and collaboration between students through information communication technology. E-learning emphasises the construction and sharing of knowledge 
through collaboration between students in an open and informal social environment. E-learning 2.0 also involves digital, mobile, connected, personal and open learning system.

According to Ehlers (2009), e-learning 2.0 can be associated with criteria, such as (1) ubiquitous learning, (2) lifelong learning, (3) learning takes place in a community, (4) learning is normal and informal, can take place anywhere (5) learning is no longer entirely dependent on the instructor or educational institution. Overall, e-learning 2.0 emphasises active teaching and learning strategies. Although e-learning 2.0 has taken over the conventional methods, the main objectives of teaching and learning are still the same: improving students' knowledge, skills, and attitudes towards what they are learning with technology.

E-learning involves pedagogy and technology. Technology facilitates the delivery of lesson content in educational contexts, either face-to-face or distance learning. Borba et al. (2016) state that mobile technology, digital learning objects, and personal learning networks have changed the classroom atmosphere that is no longer as it used to be. There are many definitions of elearning that have been used in previous studies. Ministry of Higher Education (2011) defines elearning as using information and communication technology to facilitate teaching and learning. E-learning is also defined as integrating information technology by using electronic networks to deliver the lesson content, interaction, or facilitation in teaching and learning (Noor and Hanafiah, 2012). E-learning usually explains two main things, namely technology and pedagogy, that emphasise the use of technology during teaching. Types of technology involved are computers, tablets, and the internet, while pedagogy includes online learning, blended learning, distance learning, face-to-face learning, and web-based learning (Hashim, 2012).

Online learning methods are best suited for all students because this digital revolution has led to changes in how the lesson content is accessed, consumed, discussed and shared. Unlike traditional classroom teaching, online learning helps students access the content depending on their availability and comfort, with an unlimited number of times. E-learning also provides quick delivery of lessons because students can determine their learning pace instead of following the whole group's pace. E-learning also helps students choose the specific topic to study without focusing on each area since they can skip certain areas they do not want to learn.

E-learning is usually more widely-used in higher learning institutions such as universities that offer online courses and distance learning. However, e-learning nowadays has been introduced to students since they were in secondary school. Due to the wide use of e-learning, it is very important to determine the level of knowledge on the readiness to use e-learning among form six students, especially from the science stream.

\section{Literature Review}

E-learning has been introduced since 2003. It started with the ability to use the internet and access the websites to look for information and knowledge and create a real learning environment. Electronic networks have enabled the teaching process by using e-learning. As a result, e-learning is also known as $m$-learning or mobile learning (Kassim and Ahmad, 2010). 
Offering a wide range of possibilities for sharing information and uploading documents with different formats, e-learning has certain features that facilitate and nurture the learningteaching process. E-learning allows students to interact with their teachers and lecturers more easily. It also creates a more informal learning environment compared to learning in the classroom. A study by Hazwani, Raudhiah, and Norziah (2017) stated that e-learning is more flexible than conventional methods. This is because the content and learning materials in elearning are easier to access anytime, anywhere. Besides flexibility in terms of time and place for learning sessions, e-learning can also foster and encourage self-learning among students without relying too much on teachers. Agatha and Suhaimi (2016) found that students' acceptance of elearning is influenced by the benefits provided by e-learning and efficient and simple course content.

\section{Figure 1}

Framework for E-learning Infrastructure

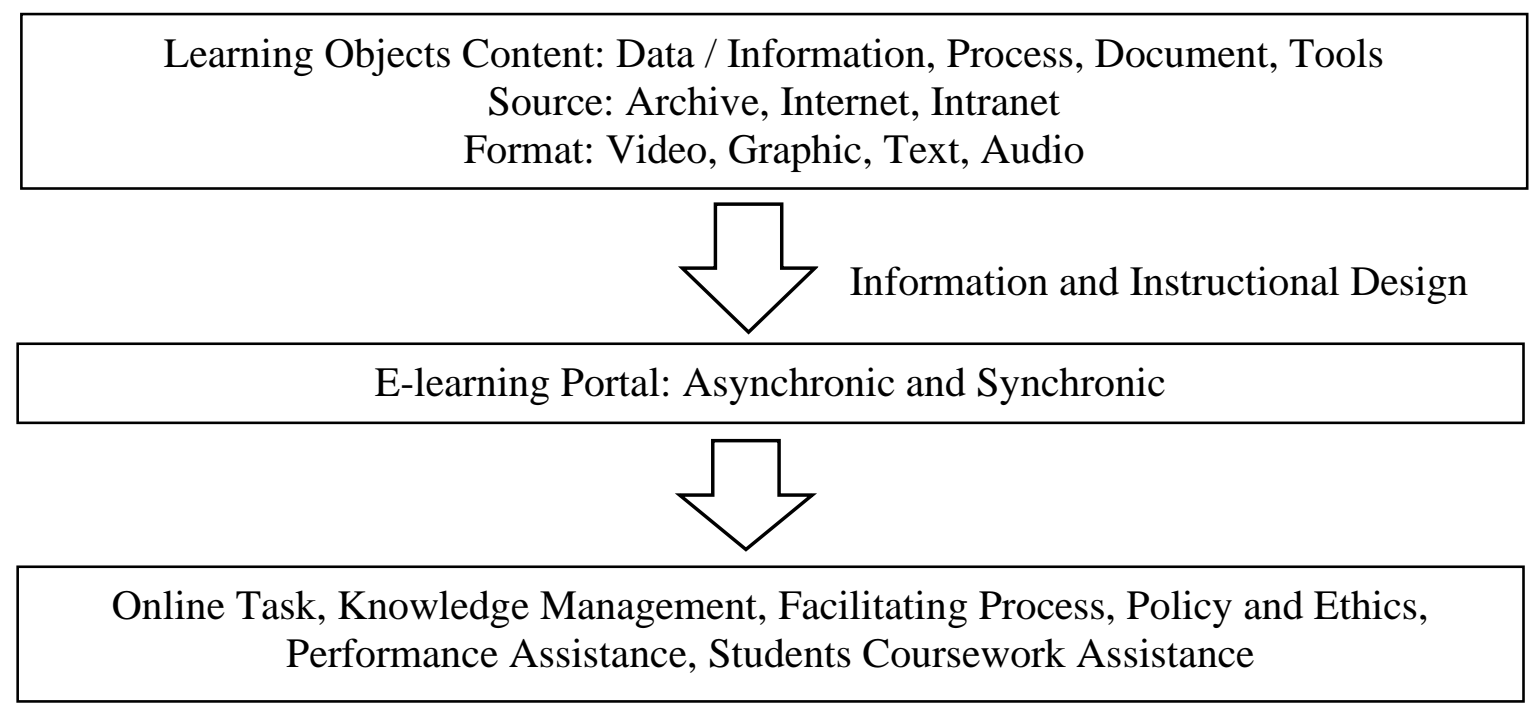

Note: Adapted from E-pembelajaran: Evolusi internet dalam pembelajaran sepanjang hayat by Zahiah binti Kassim dan Abdul Razaq bin Ahmad. 2010.

E-learning theory states that students have better control of their learning through collaborative and interactive learning. Electronic media prepares a learning environment based on the principle "just-in-time", anywhere, anytime, and anyone (Karoulis et al. 2004). E-learning provides space and opportunities for students to obtain information and improve lifelong skills with electronic media. Technology use in the teaching and learning process has affected conventional learning theories like cognitivism and constructivism. At the same time, the use of mobile devices, such as tablets and smartphones, makes e-learning easier and improves two-way communications between teachers and students, as well as between students. 
INTERNATIONAL JOURNAL OF ACADEMIC RESEARCH IN PROGRESSIVE EDUCATION AND

DEVELOPMENT

Vol. 10, No. 2, 2021, E-ISSN: 2226-6348 @ 2021 HRMARS

\section{Research Methodology}

This study is quantitative, and the survey design was used. Meanwhile, the nonprobability sampling method was used since this study's purpose is not to generalise the entire students' population. This is a descriptive study to give an overview of the level of knowledge on the readiness to use e-learning among form-six science students. This study sample comprises six form-six science stream students from Tunku Abdul Rahman Putra Form Six College in Sabak Bernam, Selangor.

This study uses a questionnaire as an instrument to collect the data. The questionnaire is adapted and modified from the previous study by Aziah and Taufik (2016). This questionnaire contains two parts, namely Part A and Part B. Part A consists of three demographic questions, while Part $B$ consists of 12 questions about the level of knowledge on the readiness to use elearning. The questionnaire uses 5-point Likert Scales, which are Strongly Disagree (SD), Disagree (D), Uncertain (U), Agree (A), and Strongly Agree (SA). The questionnaire then analysed to obtain the mean score. Mean scores between 1.00 to 2.40 indicates that the respondents have a low level of knowledge. Mean values between 2.41 to 3.80 show that the respondents have moderate knowledge and the mean value of between 3.81 to 5.00 show that the respondents have a high level of knowledge (Landell, 1997).

\section{Results and Discussion}

The findings of the study show that 31 respondents had participated in this study. Respondents were divided into $64.5 \%$ Semester 1 students and 35.5\% Semester 3 students. Lastly, $80.6 \%$ of the respondents are male, while $19.4 \%$ are female students.

Table 1 shows students' perceptions about their level of knowledge on the readiness to use e-learning. A total of 12 questions were asked. The findings show that science students in Tunku Abdul Rahman Putra Form Six College have a high level of knowledge of the readiness to use e-learning with a mean score of 3.82 . 
INTERNATIONAL JOURNAL OF ACADEMIC RESEARCH IN PROGRESSIVE EDUCATION AND DEVELOPMENT

Vol. 10, No. 2, 2021, E-ISSN: 2226-6348 @ 2021 HRMARS

\section{Table 1}

Level of Students' Knowledge of the Readiness to Use E-Learning

\begin{tabular}{clc}
\hline Item & \multicolumn{1}{c}{ Readiness to Use E-Learning } & Mean \\
\hline 1 & Use e-learning at anytime & 3.77 \\
2 & Know what e-learning is & 4.06 \\
3 & Always learn how to use e-learning & 3.87 \\
4 & Proficient in using e-learning & 3.97 \\
5 & Ready to face challenges in the use of e-learning & 3.87 \\
6 & Rarely encourages friends to use e-learning & 3.32 \\
7 & Consider the e-learning method as the preferred learning & 3.65 \\
& method & \\
8 & Use e-learning in science subjects & 3.87 \\
9 & Use e-learning to communicate with friends & 3.55 \\
10 & Use e-learning to communicate with teachers & 3.94 \\
11 & Always use e-learning to get learning materials & 4.23 \\
12 & Always take the opportunities through e-learning & 3.84 \\
\hline & $\quad$ Mean Score & 3.82 \\
\hline
\end{tabular}

The findings show that item number 11 , which is 'always use e-learning to get learning materials', recorded the highest mean value of 4.23 . This indicates that the respondents can use e-learning and have no constraints to get teachers' learning materials through e-learning. Noraffandy and Ling (2011) state that e-learning promotes active and independent learning. In this light, it encourages students to take the initiative to download the notes or learning materials from e-learning portals. They also know that many learning materials are available through elearning, which can help them improve their academic achievement. E-learning enables students to link the various resources in several varying formats due to its convenience and flexibility. Elearning plays an important role in providing flexibility by allowing students and teachers to choose when and where they teach or learn according to their professional and personal availabilities (Chang and Chang, 2012; Rani and Kant, 2013).

The findings also show that students are actually accustomed to e-learning methods. This is because it is closely related to their daily activities. Students nowadays are highly influenced by electronic devices such as smartphones, tablets, and computers, and they want personalised content at their point of need. Furthermore, e-learning through mobile technology have many benefits in terms of students' mobility, learning strategies, and a comfortable social environment (Jeng, Wu, Huang, Tan and Yang, 2010). Discussion boards and chat groups through e-learning enable students to interact with each other online and clear doubts. In addition, e-learning can act as an important tool for supporting collaborative learning through virtual methods because teachers and students can solve supervision tasks, gain new skills and use them in the teaching and learning processes together (Kopp, Matteucci and Tomasetto, 2012). 
A previous study by Faridah and Zain (2012) also found that students' level of knowledge on the use of e-learning is high. Another study by Amirudin, Rakimie and Hidayat (2015) also found that respondents responded positively to the readiness to use e-learning. This positive response shows that students have a high motivation to continue using e-learning to obtain learning materials. This could make the learning process more meaningful. If students are motivated to learn, they are more likely to be engaged and more likely to achieve their learning objectives.

E-learning can be classified as a teaching platform that positively affects the teaching and learning process. In the future, e-learning can potentially be a superior virtual learning tool because it can improve the quality of teaching and learning in our formal education systems. The implementation of e-learning has also enabled innovation in education, thus increasing educators' expertise to deliver teaching content (Amirudin, Rakimie and Hidayat, 2015). While it is still too early to see the effect of e-learning on academic achievement, we could see that elearning helps manage learning materials and assessment (Lamsah and Yusoff, 2020). Furthermore, the transmission and updating of teaching and learning materials are faster, encouraging interactive communication between teachers and students. E-learning are also user friendly and the learning materials are accessible either from within or outside the school area, providing flexible support for teachers and students. In addition, these materials potentially pose an alternative method for teaching and learning, with online evaluation and collaborative learning.

\section{Conclusion}

E-learning can be categorised as a lifelong learning method that has now been accepted by the global community, including science students in Tunku Abdul Rahman Putra Form Six College. It is important for them to start experimenting and experiencing e-learning or the form six education system will be left far behind. The outcome of the study supports that these students were exposed to the e-learning in great deal. This study also has proven that e-learning could provide greater possibilities on self-study courses among the students.

E-learning encourages students to grab the benefits of electronic tools, techniques and platforms by using it for the purpose of acquiring and sharing knowledge. The application of elearning in the teaching and learning process is an effective medium to provide more conducive learning facilities and achieve quality learning to meet the needs of the current form six generation. In other words, while traditional education is more teacher-centred, with the development of e-learning a shift towards a student-centred education can be seen especially in form six education system.

\section{Acknowledgement}

First and foremost, I would like to say thank you to all the science students and also the teachers in Tunku Abdul Rahman Putra Form Six College (KiSTARP) for giving me full cooperation and helping me to conduct this research. I also would like to say thank you to District Education Office (PPD) Sabak Bernam, and also Selangor State Education Department (JPN) for always encouraging teachers to become researchers in their classroom by Research and Development 
INTERNATIONAL JOURNAL OF ACADEMIC RESEARCH IN PROGRESSIVE EDUCATION AND

DEVELOPMENT

Vol. 10, No. 2, 2021, E-ISSN: 2226-6348 @ 2021 HRMARS

(R\&D) programs. Last, but not the least, I would like to express my sincere gratitude to my supervisor, Prof. Dr. Kamisah binti Osman. This paper and the research behind it would not have been possible without the exceptional support of my supervisor.

\section{References}

Borba, M. C., Askar, P., Engelbrecht, J., Gadanidis, G., Llinares, S., dan Angular, M. S. (2016). Blended learning, e-learning and mobile learning in mathematics education. ZDM Mathematics Education. 48, $589-610$.

Chang, I. Y., and Chang, W. Y. (2012). Effects of e-learning on learning performance - A case study on students in Tourism Department in Taiwan. Pak. J. Statist. 28(5): 633-634.

Ehlers. (2009). A participatory approach to e-learning quality. A new perspective on the quality debate. Journal for Lifelong Learning in Europe. 11.

Jamil, F., \& Retas, Z. (2012). Kesediaan penggunaan e-learning di kalangan pelajar politeknik, Kementerian Pengajian Tinggi. Jabatan Pengajian Politeknik. Jurnal Pendidikan.

Hashim, Y. (2012). Penggunaan E-Pembelajaran dalam Pengajaran dan Pembelajaran Yang Berkesan. Konvensyen Kebangsaan Pendidikan Guru (KKPG). Kuantan, Pahang.

Jeng, Y. L., Wu, T. T., Huang, Y. M., Tan, Q., \& Yang, S. J. H. (2010). The add-on impact of mobile applications in learning strategies: A review study. Educational Technology and Society. 13(3), 3-11.

Kassim, Z., \& Ahmad, A. R. (2010). E-pembelajaran: Evolusi internet dalam pembelajaran sepanjang hayat. Proceedings of Regional Conference on Knowlegde Integration in ICT.

Japuni, M. N., \& Yusof, M. H. (2012). E-Pembelajaran dalam Pengajaran dan Pembelajaran Subjek Teknologi Maklumat dan Komunikasi IPG Kampus Tawau.

Najib, M. H., Abu Bakar, N. R., \& Othman, N. (2017). E-Pembelajaran dalam kalangan pelajar di sebuah institusi pengajian tinggi Selangor (E-learning among students of higher education institutions in Selangor). Malaysian Online Journal of Education. Vol.1, 74 - 82.

Salim, M. A., Shaffai, M. R., \& Abd. Jalil, M. H. (2015). Kesedaran, Penerimaan, Keberkesanan dan Hubungkaitnya Terhadap Pelaksanaan E-Pembelajaran dalam Kalangan Pensyarah Politeknik Merlimau.

Omar, R., \& Ahmad, J. (2009). Kesedaran, penilaian dan penerimaan e- pembelajaran dalam kalangan ahli akademik (Awareness, evaluation and acceptance of e-learning among the university's academic staff). Jurnal Pendidikan Malaysia. 34(1), 155 -172

Rani, S., \& Kant. (2013). E-learning tools-A new innovation in teaching learning. Golden Research Thoughts 2(9). http://www.aygrt.isrj.net (accessed 23 February 2013).

Chear, S. L. \& Nor, M. Y. (2020). Intervensi pembelajaran di portal e-pembelajaran melalui aplikasi Whatsapp dan Telegram berdasarkan Model Lima Fasa Needham (Learning intervention in e-learning portal through Whatsapp and Telegram based on Needham Five Phase Model). Journal of Evaluation Studies in Social Sciences. Vol. 9, 11-27

Umbit, A. F., \& Taat, M. S. (2016). Faktor-faktor Yang Mempengaruhi Penerimaan E-Pembelajaran Dalam Kalangan Pelajar di Institut Pendidikan Guru di Sarawak. Jurnal IPGK BL. 13, 1 -14

Yahaya, N. \& Ling, N. N. (2011). Kesediaan penggunaan e-learning di kalangan pelajar tahun kedua kursus Sarjana Muda Sains, Komputer serta Pendidikan, Fakulti Pendidikan, 
INTERNATIONAL JOURNAL OF ACADEMIC RESEARCH IN PROGRESSIVE EDUCATION AND

DEVELOPMENT

Vol. 10, No. 2, 2021, E-ISSN: 2226-6348 @ 2021 HRMARS

Universiti Teknologi Malaysia - Satu tinjauan. Journal of Educational Science. Volume 1 (3), 121-140 